\title{
YUGOSLAV TRADE WITH EEC AND COMECON COUNTRIES
}

\author{
Mrhalo Jovanovic*
}

The purpose of this note is to summarize briefly the nature and extent of economic cooperation between Yugoslavia and two groups of countries-the EEC and COMECON. The focus of this discussion is on recent economic data indicating the scope of these relationships. The probable course of future developments is also considered.

\section{I}

\section{Economic Relations with the EEC Countrues}

In I97I the economic relations with EEC countries were significantly affected by both internal and external factors. During that year the negative trade balance with all of the EEC countries rose steadily, owing to a decrease in Yugoslav exports (to all countries except to the Federal German Republic), and to a considerable increase in imports. This unfavorable development is particularly disconcerting since one of the most dynamic regions of the world is involved-a region which is responsible for approximately 33 per cent of all exports from, and 40 per cent of all imports to, Yugoslavia. In short, the primary importance of the EEC as a market, so far as Yugoslavia is concerned, is that it provides an outlet for a relatively high percentage of Yugoslav exports, and thus is an important source of convertible currency. Such currency is required to settle the negative balance of trade, as well as the balance of payments deficit in general.

Not all EEC countries participate equally in trade with Yugoslavia. As has been true in the past, Italy and the Federal German Republic continue to be the most active Yugoslav trade partners, as regards both imports and exports. As indicated in Tables I and II, commodity exchange has been dynamic only with respect to these two, and even here, most activity was on the import side. So far as exports were concerned, an increase over previous years was noted only in deliveries to the West German market.

A review of activity in particular commodities indicates the trend of Yugoslav trade with the EEC. The EEC continues to be a very significant market for placement of national agricultural products. While a relatively unfavorable harvest affected this area of the Yugoslav economy in I97x, the average for several past years shows that the EEC market absorbs, on an average, over 50 per cent of the total Yugoslav agricultural output. The EEC market also receives nearly 60 per cent of the raw materials exported from Yugoslavia, primarily wood, textile fibers,

* Research Fellow, Foreign Trade Institute, Belgrade; Editor, Problems of Foreign Trade and Market Condttions. 
TABLE I

Yugoslav IMPORTS FROM EEC COUNTRIES

\begin{tabular}{|c|c|c|c|c|}
\hline & \multirow{2}{*}{$\begin{array}{l}\text { Percentage of total } \\
\text { Yugoslav imports in } \\
1970\end{array}$} & \multicolumn{3}{|c|}{$\begin{array}{l}\text { Monthly Averages } \\
\text { (in millions of dinars) }\end{array}$} \\
\hline & & 1969 & 1970 & 1971 \\
\hline 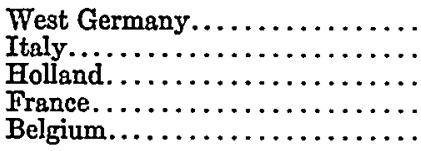 & $\begin{array}{r}19.7 \\
13.2 \\
1.7 \\
3.8 \\
1.4\end{array}$ & $\begin{array}{r}404.7 \\
333.0 \\
37.2 \\
75.1 \\
22.8\end{array}$ & $\begin{array}{r}590.8 \\
393.8 \\
51.8 \\
114.5 \\
41.6\end{array}$ & $\begin{array}{r}640.4 \\
433.6 \\
49.7 \\
134.9 \\
29.9\end{array}$ \\
\hline
\end{tabular}

TABLE II

Yugoslav Exports to EEC Countries

\begin{tabular}{|c|c|c|c|c|}
\hline & \multirow{2}{*}{$\begin{array}{l}\text { Percentage of total } \\
\text { Yugoslav exports in } \\
1970\end{array}$} & \multicolumn{3}{|c|}{$\begin{array}{l}\text { Monthly Averages } \\
\text { (in millions of dinars) }\end{array}$} \\
\hline & & 1969 & 1970 & 1971 \\
\hline 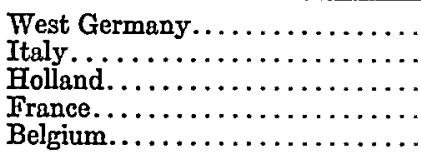 & $\begin{array}{r}11.8 \\
15.2 \\
1.6 \\
3.8 \\
0.6\end{array}$ & $\begin{array}{r}168.6 \\
236.4 \\
23.6 \\
50.8 \\
12.2\end{array}$ & $\begin{array}{r}205.8 \\
265.2 \\
28.1 \\
66.1 \\
9.9\end{array}$ & $\begin{array}{r}211.7 \\
237.3 \\
25.0 \\
56.7 \\
7.6\end{array}$ \\
\hline
\end{tabular}

and ores. However, Yugoslav industry supplies the EEC with only 20 to 30 per cent of its total imports of semi-finished goods-chiefly products of non-ferrous metallurgy, non-metal industrial goods, textiles, paper and cellulose, leather, and metal processing items. The participation of the EEC in Yugoslav exports from other sectors also remained low in I97r. This was particularly true with regard to capital investment goods and chemical products. Machinery and transport vehicles accounted for only I3 per cent of the total exports to the EEC market. There are, however, favorable prospects for an increase of exports as the potential for development is realized and cooperation in production between domestic enterprises and foreign partners is strengthened. This is particularly true in the fields of shipbuilding, the rolling stock industry, electroindustry, machine building, and other industrial sectors. On the other hand, the Yugoslav economy has absorbed a large number of hard goods from EEC producers. For instance, imports of industrial goods constituted ninetenths of the total exports from the EEC in I97r.

In May, 1970, a three-year trade agreement between Yugoslavia and the EEC came into force, I971 being the first calendar year of its operation. This agreement provides for a harmonized development and promotion of economic cooperation. While its effects will not become fully apparent until after the conclusion of the three-year period, the agreement has already produced some indication of its significance for Yugoslavia. But its real significance lies in the fact that an atmosphere generally conducive to further development of economic relations with countries of this in- 
tegrated area has been created. The agreement has provided the mechanism for solving concrete questions in the area of mutual commodity exchange. A number of external factors suggest that the potentialities of the agreement will be fully pursued. These include the geographic proximity of the countries, as well as their complementary economies (particularly as regards Italy and West Germany), and their technological connections, pre-existing industrial cooperation, the evergrowing tourist trade, and cross-migration of labor.

It is particularly important for the development of commodity exchange and other forms of economic cooperation that the most favorable treatment be mutually granted. Recognizing this, the agreement supports the efforts of the Yugoslav economy to integrate more completely with both the European and international markets. The process of creating more efficient ties with the more industrialized European economies is aimed at increasing the global productivity of the Yugoslav economy, thereby raising the standard of living in Yugoslavia. Furthermore, on the industrial level, cooperation with multinational companies in the form of industrialtechnical collaboration, mutual deliveries, and joint appearance on the markets can be achieved with greater ease in a more fully integrated, transnational market.

The recent decision to expand the EEC, and the concomitant increased integration of Western Europe, will probably have both positive and negative consequences so far as Yugoslavia is concerned. While all of the effects of this historic decision will not be known for some time, certain observations can now be made. The agreement between Yugoslavia and the EEC that was concluded in r970 will be binding on the new members. This is a plus for Yugoslavia since the sphere of its trading efforts will automatically be increased. However, since new members must adopt the inward-looking agricultural policies of the EEC, further difficulties will arise for the Yugoslav economy since agricultural products command such a prominent place in the countries' trade relationship. This will be particularly true with regard to Yugoslav-British agricultural trade. New relationships will have to be developed in the labor market as well, resulting from the appearance of a labor surplus in Great Britain, especially in the industrial labor sector.

\section{II}

\section{Economic Relations with COMECON Countries}

The development of economic relations with all socialist countries of Eastern Europe has continued in a stable fashion. Compared with I969, the commodity exchange increased in planned proportions. During the first two months after devaluation, imports as a whole rose slightly, while exports remained relatively the same. However, the present situation is generally more favorable as compared to earlier periods. During the past year imports were successfully stimulated by credits and appropriate foreign trade agreements.

The regional structure of the Yugoslav commodity exchange with COMECON countries shows that relations established only a few years ago have remained gen- 
TABLE III

Yugoslav Imports from COMECON Countries

\begin{tabular}{|c|c|c|c|c|}
\hline & \multirow{2}{*}{$\begin{array}{l}\text { Percentage of total } \\
\text { Yugoslav imports in } \\
1970\end{array}$} & \multicolumn{3}{|c|}{$\begin{array}{l}\text { Monthly Averages } \\
\text { (in millions of dinars) }\end{array}$} \\
\hline & & 1969 & 1970 & 1971 \\
\hline 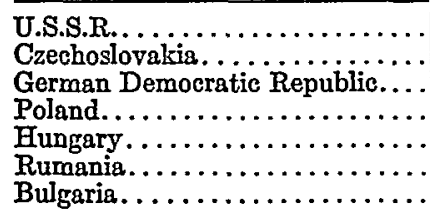 & $\begin{array}{l}6.7 \\
5.3 \\
2.6 \\
1.8 \\
1.7 \\
1.2 \\
1.1\end{array}$ & $\begin{array}{r}175.2 \\
124.9 \\
80.9 \\
48.9 \\
24.0 \\
26.0 \\
24.0\end{array}$ & $\begin{array}{r}201.2 \\
157.8 \\
77.3 \\
53.9 \\
51.1 \\
37.0 \\
34.2\end{array}$ & $\begin{array}{r}296.4 \\
169.5 \\
96.2 \\
78.9 \\
79.4 \\
55.5 \\
48.2\end{array}$ \\
\hline
\end{tabular}

TABLE IV

Yugoslav Exports to COMECON Countrues

\begin{tabular}{|c|c|c|c|c|}
\hline & \multirow{2}{*}{$\begin{array}{c}\text { Percentage of total } \\
\text { Yugoslav exports in } \\
1970\end{array}$} & \multicolumn{3}{|c|}{$\begin{array}{l}\text { Monthly Averages } \\
\text { (in millions of dinars) }\end{array}$} \\
\hline & & 1969 & 1970 & 1971 \\
\hline 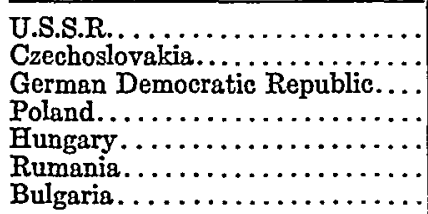 & $\begin{array}{r}14.4 \\
5.3 \\
3.0 \\
3.4 \\
2.8 \\
1.8 \\
1.3\end{array}$ & $\begin{array}{r}215.0 \\
65.4 \\
45.9 \\
48.8 \\
45.9 \\
24.7 \\
24.0\end{array}$ & $\begin{array}{r}251.6 \\
92.9 \\
53.2 \\
59.2 \\
49.8 \\
31.1 \\
23.0\end{array}$ & $\begin{array}{r}250.4 \\
95.5 \\
63.3 \\
78.2 \\
60.1 \\
38.1 \\
28.9\end{array}$ \\
\hline
\end{tabular}

erally stable. As Tables III and IV suggest, the U.S.S.R. is the most important foreign trade partner in this region. It is responsible for more than one-third of the total Yugoslav commodity exchange with COMECON countries in both directions. Other countries, according to their degree of participation in Yugoslav commodity exchange, are divided into two groups. Czechoslovakia, the German Democratic Republic, and Poland rank among the more important trade partners, while neighboring Hungary and Bulgaria have occupied a very modest place in the Yugoslav foreign trade structure. In I97x, however, Hungary played a more important role. If Hungary continues in this new direction, it could become a very important economic partner, both in relations with the socialist region, and in Yugoslav foreign trade relations generally.

The commodity structure indicates that imports of COMECON countries from Yugoslavia consist chiefly of finished and semi-finished products. These commodities account for roughly 80 per cent of COMECON imports of Yugoslav goods, while primary products are responsible for only about 20 per cent of the total. As this suggests, the structure of Yugoslav exports to COMECON countries differs from that of Yugoslav exports in general, for COMECON countries participate more intensively in exports from particular sectors of the Yugoslav economy than do other 
regions. This primarily concerns Yugoslav exports of machines and transport systems, chemical products, wines and liquors, and, to a smaller extent, semi-finished products.

A more detailed analysis of individual sectors shows that Yugoslav exports to COMECON countries consist mainly of some thirty items or groups of items, a number of which are steadily rising. As regards industrial goods, Yugoslav exports include pharmaceutical products, fertilizers, dyes and varnishes, some products of both ferrous and non-ferrous metallurgy (steel bars and pipes, copper and aluminum sheets, lead, and so on), and capital goods-ships and marine engines, rolling stock, components for motor vehicles, farm combines, cables and wires, telephone equipment, transformers, and other electric equipment. Export of consumer goods involves principally furniture, ready-made clothing, and footwear.

Primary products comprise one-third of Yugoslavia's total imports from COMECON countries. These include solid and liquid fuels, cotton, and synthetic rubber. Imports of semi-finished products are composed mainly of pig iron, sheet metal, aluminum, cotton fabrics, and tires. Imports of capital goods and other equipment embrace heavy machines (such as excavators), transport vehicles, machine tools, tractors, and various apparatus and instruments, while general consumer goods imported include passenger vehicles, ready-made clothing, and toys.

The economic development of the COMECON countries is regarded as a promising development in Yugoslavia. Moves toward the greater independence of individual COMECON countries foster greater flexibility in trading arrangements and suggest new possibilities for greater increased cooperation between Yugoslav industries and those of the COMECON countries. At the same time, this increasing openness is conducive to the introduction of modern technology, which requires exposure to developments in other countries. New technological processes offer broad possibilities for a more economical use of resources on both sides which presently are either insufficiently developed or not used at all.

Cooperation with, and presence in, the COMECON commissions for individual sectors offers Yugoslav economic organizations the possibility to examine the output capacities and developmental problems of those sectors. Yugoslav manufacturers are particularly interested in fostering a spirit of cooperation in the areas of energy, metallurgy, agriculture, transport, and construction.

Further extension of relations with COMECON countries is foreseen, although the focus is currently more on the quantitive than the qualitative aspects of cooperation. It is believed that commodity exchange can be extended by 20 to 30 per cent by including new items. Further expansion of assortments is also foreseen. The method of payments system will remain generally unchanged. In spite of Yugoslav efforts, trade transactions will continue to be based on the clearing system. However, a bilateral system of payments has been introduced.

On the financial level, further progress has been made as a result of new interbank arrangements. The creation of interbank consortiums, which include a con- 
vertibility clause, represents a significant development which should eventually lead to wider use of the convertible method of payment.

In the field of credit operations, some changes in formal credit arrangements are foreseen. Interstate credit arrangements, or contracts covered by the guarantees or super-guarantees of the Yugoslav government, should be superseded by more flexible arrangements between the parties directly concerned. It is expected, therefore, that on the Yugoslav side the only signing parties will be banks or interested economic organizations. The first steps in this direction were made by the Yugoslav Investment Bank, which concluded an agreement for financing the construction of thermoelectric equipment and various other machinery for the Smederevo Steel and Iron Works.

Similarly, creation of pure credit arrangements, not involving any combination with commodity credits, is expected. Both sides are interested in using this approach to promote Yugoslav non-ferrous production, particularly for the purpose of doubling the output of lead, zinc, and antimony, for development of bauxite deposits, and for increasing capital investments in the aluminum industry generally. The U.S.S.R. is ready to grant medium-term financial credits for expansion of productive capacities for certain specified items needed by Soviet industry. Possibilities also exist for involving the COMECON International Investment Bank in financing development of Yugoslav industrial plant capacities. On the whole, it may be said that to the extent that participation in COMECON assists Yugoslavia in overcoming both economic and non-economic difficulties, industrial and financial cooperation with COMECON countries becomes an increasingly significant component of the Yugoslav economy, strengthening its multi-sided development. 